\title{
操縦安定性改善のためのアクティブスタビライザと 電動パワーステアリングの分散制御系設計*
}

\author{
山 本 敬 一*1, 西 村 秀 和*1
}

\section{Distributed Control System Design for Active Stabilizer and Electric Power Steering Improving Driving Stability}

\author{
Kei-ichi YAMAMOTO and Hidekazu NISHIMURA*2 \\ *2 Graduate School of System Design and Management, Keio University, \\ 4-1-1 Hiyoshi, Kohoku-ku, Yokohama-shi, Kanagawa, 223-8526 Japan
}

\begin{abstract}
In this paper, a distributed control system for an active stabilizer and an electric power steering (EPS) is designed in order to improve the performance on vehicle agility and stability. A full vehicle simulation model with the active stabilizer and the EPS is derived and used to evaluate the performance for the distributed controllers design. A controller for the active stabilizer is designed using the linear quadratic (LQ) control theory to balance competing goals for the roll reduction of a vehicle body during cornering and the improvement of the ride comfort on a rough road and to especially take the road surface disturbance to the steering system into account. Also a controller for the EPS considering the self-aligning torque generated from the vehicle system with the stabilizer is designed to assist the steering of the driver by applying the $H_{\infty}$ control theory. It is verified that the distributed control system applied to the full vehicle model is effective to not only reduce the roll motion and the steering torque during cornering but also improve the driving stability and the ride comfort on the rough road.
\end{abstract}

Key Words : Automobile, Modeling, Motion Control, Vibration Control, Vehicle Dynamics, Active Stabilizer, Electric Power Steering, Ride Comfort, Driving Stability

\section{1.はじめに}

自動車の走行安定性の向上や環境への配慮の要求が 高まっている. そのため, 車両の姿勢安定性能および 乗り心地性能に寄与するサスペンションシステムの研 究開発が盛んに行われている. また，油圧式に替わり 環境負荷の低減を可能とする電動パワーステアリング (electric power steering, EPS) の普及が進んでいる.

サスペンションシステムに関しては, 不整路面での 乗り心地改善のみならず，操縦安定性を改善するため に車体の姿勢安定化を図る試みがなされている，須田 らは左右輪の電磁サスペンションのデバイスを電気的 に連携し，サスペンションにスタビライザ機能をもた せることでロール角を低減する方法を提案している(1). また, 高橋らは剛性・減衰両可変セミアクティブサス ペンションを有するフルビークルモデルに対して，人 間の振動感受特性や操舵による車体挙動に影響を与え る周波数帯域を考慮した制御系を設計している(2). そ

* 原稿受付 2009 年 9 月 25 日。

*1 正員, 慶應義塾大学大学院システムデザイン・マネジメント 研究科 (拜 223-8526 横浜方港北区日吉 4-1-1)

E-mail : h.nishimura@sdm.keio.ac.jp
して, 車体の上下振動の抑制, および可変剛性機能に より操舵時のロール角の低減を図っている.

近年では，操舵時のロール運動をより効果的に低減 するために，ロール方向に限定した車体の姿勢制御を 行う油圧式のアクティブスタビライザが開発されてい る(3). また，武馬らは低消費エネルギでロール角を低 減できる電動式のアクティブスタビライザを開発して いる(4). そこでは, 車速, 舵角, 横加速度の情報から, 通常のスタビライザ装着車の約 $1 / 2$ となる目標ロール 角を求め，その目標値に追従させるように制御が施さ れている. これに対して, 著者らは操舵時のロール角 の低減のみならず，乗り心地に関連する不整路面での ロール振動の抑制に有効なアクティブスタビライザの 制御系を力学モデルに基づいて設計している(5).

一方, ドライバの操舵をアシストするEPS は車両 の姿勢変動や路面状態の変化をドライバに伝達するた め, ドライバが自動車を安全に運転するために必要と なる適切な操舵感覚の実現に大きく影響を及ぼす。そ のため, 操舵感の向上や操舵系に作用する外乱の抑制 などに対して高い制御性能が期待され，開発が進めら 
れている(6)(7)(8). 荒井らは二輪モデルを対象に, EPS のロバスト制御系を設計している ${ }^{(8)}$ 。そこでは, 操舵 に伴って車両系から操舵系に作用するセルフアライニ ングトルクを外乱として考慮することで制御系設計を 行い, 走行特性や操舵感の改善を図っている. 操舵に よって生じる車体のロール運動や不整路面走行時に夕 イヤを介して操舵系に伝達する外乱をアクティブスタ ビライザで抑制しつつ, EPS を用いることで車両の操 縦安定化が期待できる.

そこで本論文では, アクティブスタビライザと EPS の両者功なる分散制御系の設計指針を示す．従来の アクティブスタビライザや EPS 単体と比較して制御 性能の優位性を示すものではないが, 分散制御系設計 ではアクティブスタビライザと EPS の両者の制御性 能を考虑する. このため, これらのシステムを連成さ せたフルビークルモデルを構築する. アクティブスタ ビライザの制御系設計に際しては, ロール角の低減と ロール振動の抑制が主たる目的となるが, 特に, 操舵 系への路面外乱の作用を抑制することが重要となるこ とを示す. EPS の制御系設計に際しては, 操舵時にス タビライザ反力が操舵系に加わることを考慮し，これ を含めたセルフアライニングトルクを外乱とみなして いる. 特に, 操舵アシスト制御系の設計指針として, スタビライザの負担軽減に寄与するために, 車体重心 に作用する横力の低減を図ることが重要となることを 示す.

\section{2. モデリング}

$2 \cdot 1$ アクティブスタビライザ付き車両モデル＼cjkstart本 論文では, 図 1 に示すようにアクティブスタビライザ をフロントとリアのサスペンションシステムに取り付 けた車両モデル ${ }^{(5)} に$, EPS を連成させたフルビークル モデルを導出する. フルビークルモデルの導出には文 献 (2)を参考にし, 車体の上下運動, ロール運動, ピッ

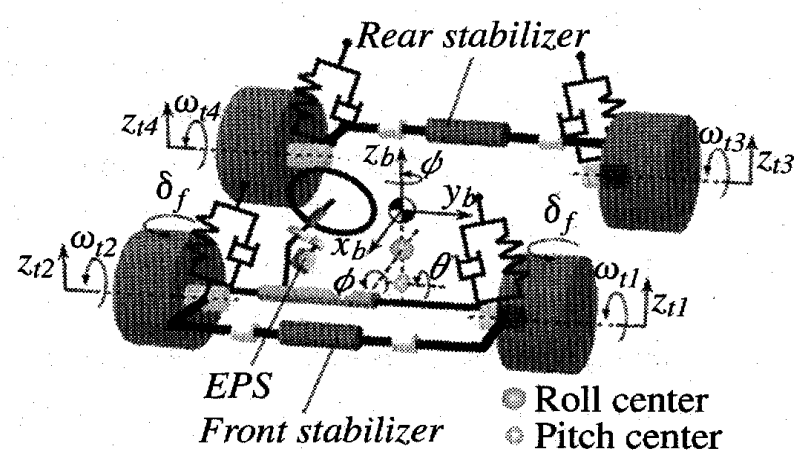

Fig. 1 Full vehicle model with active stabilizer and EPS
チ運動，ならびに前輪操舵による車両のヨー運動を再 現する. 車両モデルの記号および主要車両諸元を付録 に示す.

フロント用スタビライザのカ学モデルを図 2 に示す. スタビライザは, ブッシュ部と車輪の鈆直方向にそれ ぞれ左右逆相にスタビライザ反力 $F_{s j}(j=f, r)$ を発生 し，車体のロール運動に対してのみ作用する。図 2(a) に示すパッシブスタビライザでは, 長さW $W$ のタビ ライザバーにばね鋼が使われており，左右輪が逆相に ストロークするとき，あるいは車体にロール角が生じ たときバーがねじられ，バーのねじり剛性 $K_{s t}$ によっ てて発生するスタビライザ反力

$$
\begin{aligned}
& F_{s f}=K_{s t f} \gamma_{f}=K_{s t f} \frac{z_{t 2}-z_{t 1}+W \phi}{a}=\frac{T_{s f}}{a} \\
& F_{s r}=K_{s t r} \gamma_{r}=K_{s t r} \frac{z_{t 4}-z_{t 3}+W \phi}{a}=\frac{T_{s r}}{a}
\end{aligned}
$$

によりロール角が低減される.ここで, $\gamma_{j}$ はバーのね じれ角，aはスタビライザアーム長さである.

一方, 図 2(b) に示すアクティブスタビライザでは, スタビライザバーの中央に制御トルク $T_{a j}$ を発生する アクチュエータを取り付け, スタビライザ反カ

$$
F_{s j}=\frac{T_{a j}}{a}
$$

を発生させる. また, スタビライザ反力 $F_{s j}=0$ とす ることで, スタビライザなしのノーマルサスペンショ ンとして用いる.

図3(a), (b) に示すサスペンションシステムを含む車

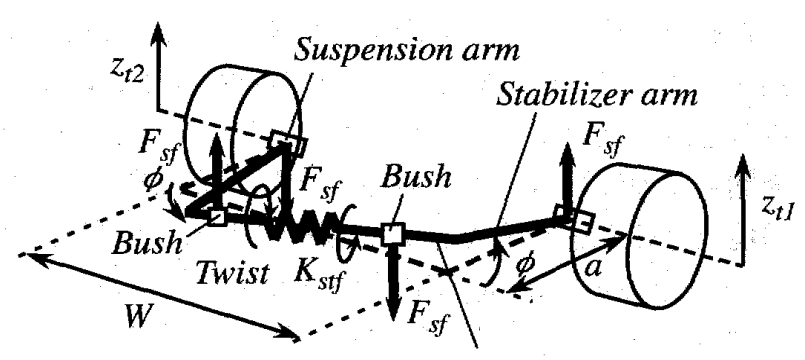

Stabilizer bar

(a) Passive stabilizer

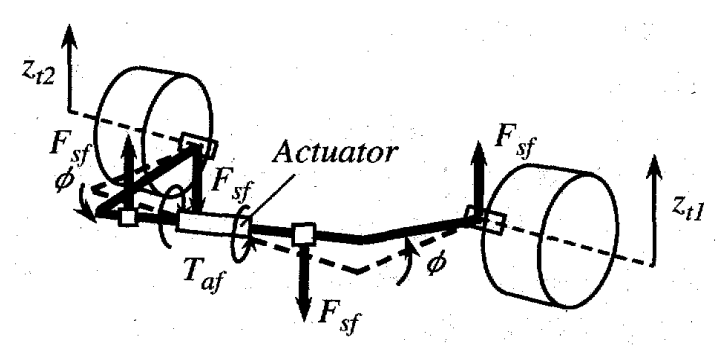

(b) Active stabilizer

Fig. 2 Dynamical model of front stabilizer 


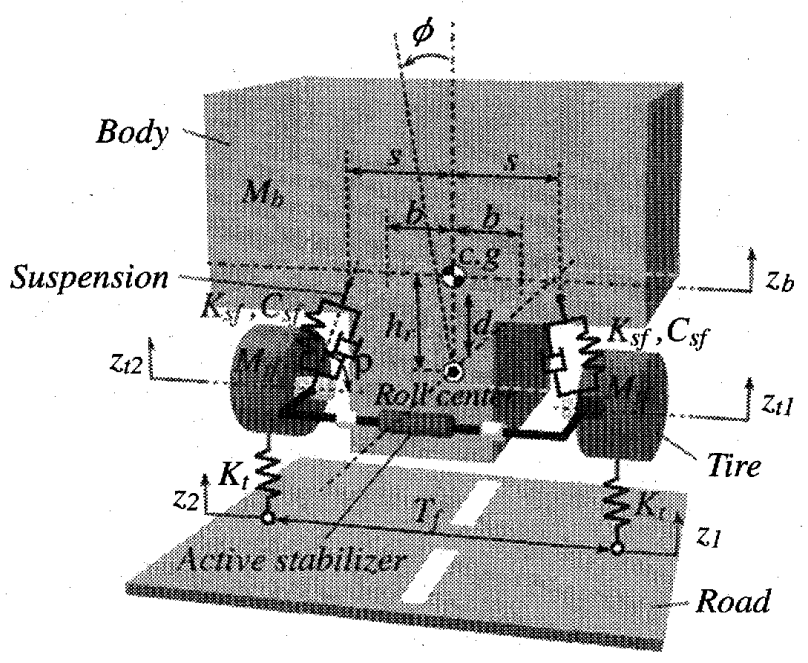

(a) Front view

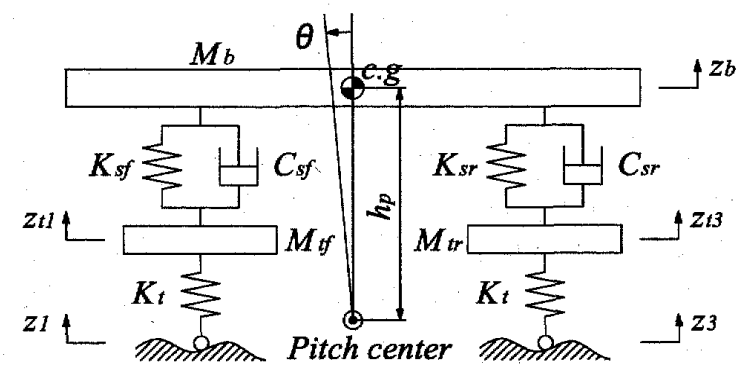

(b) Side view

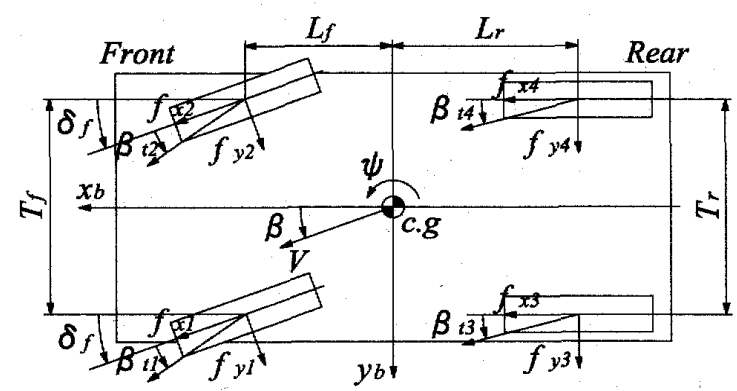

(c) Top view

Fig. 3 Dynamical model of full vehicle

再の力学モデルを導出する.ただし，ロール角および ピッチ角は十分小さいものとし，ロールセンタとピッ チセンタは車両に固定され，キャンバ角と慣性乗積は 無視できるものとする. 車体の鈶直方向, 各車輪の鉛 直方向, 車体のロール方向, 車体のピッチ方向の運動 方程式はそれぞれ次式によって与えられる.

$$
\begin{aligned}
& M_{b} \ddot{z}_{b}=\sum_{i=1}^{4} f_{s v i} \\
& M_{t f} \ddot{z}_{t 1}=-f_{s v 1}+f_{z 1}+F_{s f} \\
& M_{t f} \ddot{z}_{t 2}=-f_{s v 2}+f_{z 2}-F_{s f} \\
& M_{t r} \ddot{z}_{t 3}=-f_{s v 3}+f_{z 3}+F_{s r} \\
& M_{t r} \ddot{z}_{t 4}=-f_{s v 4}+f_{z 4}-F_{s r}
\end{aligned}
$$

$$
\begin{aligned}
I_{r} \ddot{\phi}= & \left(f_{s v 1}-f_{s v 2}\right) s+\left(f_{s v 3}-f_{s v 4}\right) s \\
& +\left(f_{s h 1}-f_{s h 2}\right) d+\left(f_{s h 3}-f_{s h 4}\right) d \\
& -2 b F_{s f}-2 b F_{s r}+M_{b} g h_{r} \phi+F_{y} h_{r} \\
I_{p} \ddot{\theta}= & -L_{f}\left(f_{s v 1}+f_{s v 2}\right)+L_{r}\left(f_{s v 3}+f_{s v 4}\right) \\
& +M_{b} g h_{p} \theta-F_{x} h_{p}
\end{aligned}
$$

ここで, $f_{s v i}, f_{s h i}(i=1, \cdots, 4)$ はサスペンションの鉛直 方向力と水平力向力, $f_{z i}\left(=K_{t} z_{g i}\right)$ 沙銷直夕イヤ力であ る. 車体重心位置に作用する式 (10) における前後力 $F_{x}$ と式 (9) に方ける横力 $F_{y}$ は, 図 3(c) に示す車両の 水平面内の力学モデルから得られ，その詳細は文献 ${ }^{(5)}$ に示す. 図3(c) に示される $f_{x i}$ と $f_{y i}$ は前後タイヤカと 横タイヤ力であり，Burckhardt/Kiencke モデル ${ }^{(9)} に$ 基 づく非線形領域を考慮したタイヤモデルを用いて算出 する. $\delta_{f}$ は操舵系から与えられる前輪実舵角である.

力学モデルに基づいてアクティブスタビライザの制 御系設計を行うため, 運動方程式の状態空間表現が必 要である。状態量 $\boldsymbol{x}$, 制御入力 $\boldsymbol{u}$, 外乱 $\boldsymbol{d}$ をそれぞれ

$$
\begin{aligned}
& x=\left[\begin{array}{llllllll}
z_{s 1} & z_{s 2} & z_{s 3} & z_{s 4} & z_{g 1} & z_{g 2} & z_{g 3} & z_{g 4}
\end{array}\right. \\
& \left.\begin{array}{lllllllll}
\phi & \theta & \dot{z}_{b} & \dot{z}_{t 1} & \dot{z}_{t 2} & \dot{z}_{t 3} & \dot{z}_{t 4} & \dot{\phi} & \dot{\theta}
\end{array}\right]^{T}, \\
& \boldsymbol{u}=\left[\begin{array}{ll}
T_{a f} & T_{a r}
\end{array}\right]^{T}, \boldsymbol{d}=\left[\begin{array}{llllll}
F_{x} & F_{y} & \dot{z}_{1} & \dot{z}_{2} & \dot{z}_{3} & \dot{z}_{4}
\end{array}\right]^{T}
\end{aligned}
$$

とすると, 車体重心位置での前後力 $F_{x}$ と横力 $F_{y}$, 路 面速度外乱 $\dot{z}_{i}$ を受ける車両モデルの状態方程式

$$
\dot{x}=A x+B_{u} u+B_{d} d
$$

を得る.ここで, 状態量 $\boldsymbol{x}$ 中の $z_{s i}$ は車輪と車体重心 との間の鉛直方向の相対変位, $z_{g i}$ は路面と車輪との 間の鉛直方向の相対変位であり，それぞれ次式によつ て表される。

$$
z_{s i}=z_{t i}-z_{b}, \quad z_{g i}=z_{i}-z_{t i}
$$

2.2 電動パワーステアリングモデル＼cjkstart操舵系の 力学モデルを図 4 に示す.このモデルは操舵系をハン ドル側のステアリング軸とモータ側のステアリング軸 に分け，タイヤの回転運動をすべてモータ側のステア リング軸回りの回転運動に換算した 2 慣性モデルであ る(8).このモデルから操舵系の運動方程式は

$$
\begin{aligned}
& I_{h} \ddot{\theta}_{h}+C_{h} \dot{\theta}_{h}+K_{h}\left(\theta_{h}-\alpha\right)=T_{h} \\
& I_{m} \ddot{\alpha}+C_{m} \dot{\alpha}+\left(K_{h}+\frac{\xi C_{f}}{N^{2}}\right) \alpha-K_{h} \theta_{h}=T_{m}+d_{s a t}
\end{aligned}
$$

となる.ここで, $\alpha$ はピニオン角であり, 実舵角 $\delta_{f}$ と の関係は，ステアリングギア比 $N$ を用いて

$$
\delta_{f}=\frac{\alpha}{N}
$$




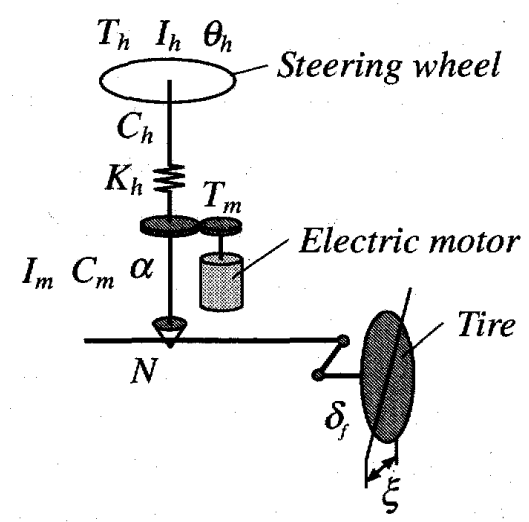

Fig. 4 Dynamical model of electric power steering

と表され，2.1 節の図 3(c) に示す実舵角 $\delta_{f}$ に入力さ れる. また，式(14)の右辺第二項の $d_{\text {sat }}$ はセルフアラ イニングトルク中の車両特性に関わる部分であり, 線 形な領域で変化するものと仮定すると, 次式のように 表される.

$$
d_{s a t}=\frac{\xi C_{f}\left(L_{f}+L_{r}\right)}{N L_{r} M g}\left(W_{t 1} \frac{v_{y 1}}{v_{x 1}}+W_{t 2} \frac{v_{y 2}}{v_{x 2}}\right)
$$

ここで, $W_{t 1}, W_{t 2}$ は車体姿勢や路面外乱によって変化 するタイヤの鈶直荷重であり，左右の前輪に対して， それぞれ次式のように表すことができる.

$$
W_{t 1}=f_{z 1}+\frac{L_{r} M g}{2\left(L_{f}+L_{r}\right)}, \quad W_{t 2}=f_{z 2}+\frac{L_{r} M g}{2\left(L_{f}+L_{r}\right)}
$$

式 (16) の $d_{s a t}$ を操舵系への外乱とみなし, 状態量 $\boldsymbol{x}_{s}$, 制御入力 $u_{s}$, 外乱 $\boldsymbol{w}_{s}$ をそれぞれ

$$
\boldsymbol{x}_{s}=\left[\begin{array}{cccc}
\alpha & \dot{\alpha} & \theta_{h} & \dot{\theta}_{h}
\end{array}\right]^{T}, \quad u_{s}=T_{m}, \quad \boldsymbol{w}_{s}=\left[\begin{array}{ll}
T_{h} & d_{s a t}
\end{array}\right]^{T}
$$

とおくと, 操舵系 $P(s)$ の状態力程式と出力方程式は

$$
\begin{aligned}
& \dot{\boldsymbol{x}}_{s}=\boldsymbol{A}_{s} \boldsymbol{x}_{s}+\boldsymbol{B}_{s u} u_{s}+\boldsymbol{B}_{s w} \boldsymbol{w}_{s} \\
& y_{s}=\boldsymbol{C}_{s} \boldsymbol{x}_{s}
\end{aligned}
$$

となる. 出力 $y_{s}$ はセンサトルク $T_{s}=K_{h}\left(\theta_{h}-\alpha\right)$ であ り, 制御器へのフィードバック信号として用いる.

\section{3. 分散制御系設計}

3.1 アクティブスタビライザの制御系設計 操 舵時のロール角低減と乗り心地に関連する不整路面で のロール振動を抑制させるために，LQ 制御理論を用 いて，アクティブスタビライザの状態フィードバック 制御系を設計する ${ }^{(5)}$. ここで, 状態量 $x$ の状態変数は すべて検出可能であるとする.

状態方程式 (11) の制約のもとで, 線形 2 次形式の評 価関数

$$
J=\int_{0}^{\infty}\left[\boldsymbol{x}^{T} \boldsymbol{Q x}+\boldsymbol{u}^{T} \boldsymbol{R} u\right] d t
$$

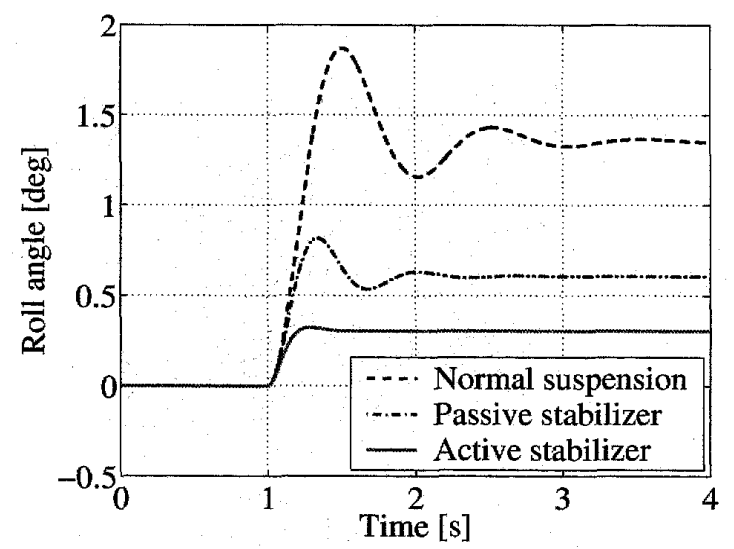

Fig. 5 Step response of vehicle model with active stabilizer to lateral force

を最小にする制御入力は次式によって与えられる.

$$
\boldsymbol{u}=-\boldsymbol{F} \boldsymbol{x}
$$

ここで, $\boldsymbol{Q}, \boldsymbol{R}$ は設計仕様で与えられる評価関数の重み 係数，F は状態フィードバックゲインである. 重み係 数 $\boldsymbol{Q}$ では, ロール角とロール角速度に重み付けした。 ロール角に対する重み係数の調整では, ステップ状の 横力外乱 $F_{y}$ に対する定常ロール角がパッシブスタビラ イザを用いた場合の約 $1 / 2$ になるロール剛性に設定し た. ロール角速度に対する重み係数の調整では, ロー ル振動の抑制が主たる目的となるが, 操舵系への路面 外乱の作用を抑制することが重要となる。そこで, 操 舵系まで含めてシミュレーションを行う 4 章では不整 路面での操舵トルクの抑制を加味して, 重み係数の調 整を行った. 調整した重み係数 $\boldsymbol{Q}, \boldsymbol{R}$ を以下に示す.

$$
\begin{aligned}
& Q=\operatorname{diag}\left[\begin{array}{lllll}
0_{1 \times 8} & 7.17 \times 10^{8} & 0_{1 \times 6} & 3.52 \times 10^{5} & 0
\end{array}\right] \\
& \boldsymbol{R}=\operatorname{diag}\left[\begin{array}{ll}
1 & 1
\end{array}\right]
\end{aligned}
$$

車体が操舵時に横力外乱を受けることを想定し，車 体重心にステップ状の横力外乱 $F_{y}=1 \mathrm{kN}$ を時刻 $t=1 \mathrm{~s}$ で作用させたときのロール角の時刻歴応答を図 5 に示 す. 破線はノ一マルサスペンション車両モデル, 一点 鎖線はパッシブスタビライザ付き車両モデル，実線は アクティブスタビライザ付き車両モデルとした場合の 応答である. なお, パッシブスタビライザの場合, ス タビライザバーの剛性によって発生するロール振動を 抑制するために, サスペンションの隇衰係数を 2 倍に している.

図 5 に示すように，パッシブスタビライザの場合の 定常ロール角は, ノーマルサスペンションの場合と比 較して約 $62 \%$ 低減されている.アクティブスタビラ イザの場合では，定常ロール角がパッシブスタビライ ザの場合の約 $1 / 2$ に低減されているここが確認できる. 


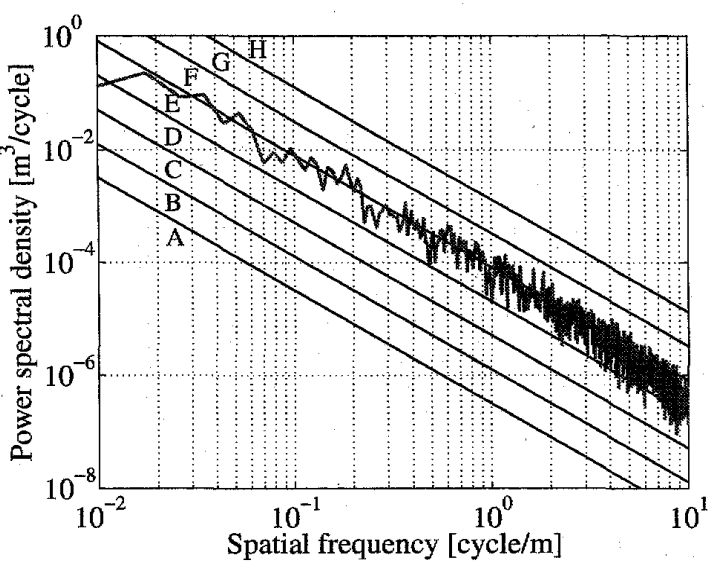

(a) PSD of road disturbance

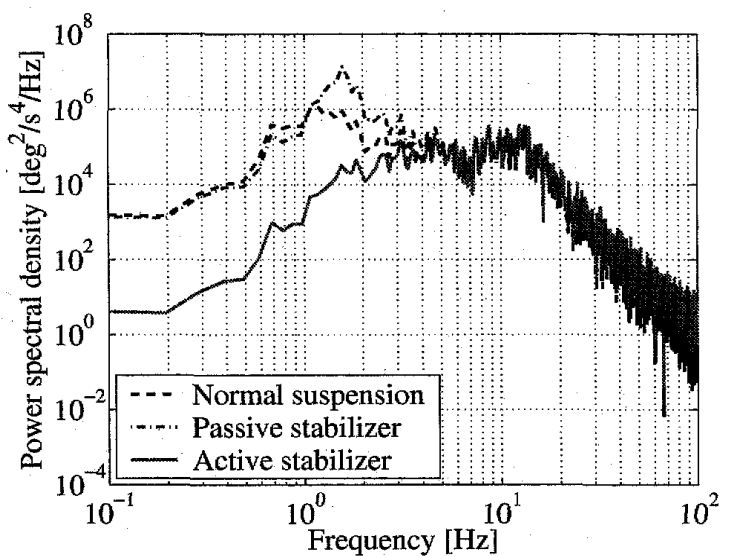

(b) PSD of roll angular acceleration to road disturbance

Fig. 6 Characteristics of vehicle model with active stabilizer to ISO road disturbance

次に, ISO で規格化されている非舖装悪路に相当す

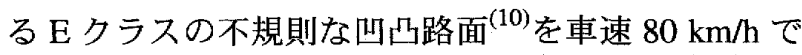
走行する場合を想定し，そのとき車体に生じるロール 振動を評価した．図6(a) は，空間周波数に対する $\mathrm{E} ク$ ラス相当の路面変位のパワースペクトル密度 (power spectral density, PSD) である. シミュレーションでは, Eクラス路面を各輪独立に作成し，不規則路面入力と して車両モデルに与えた．図 6(b) は，路面外乱に対す るロール角加速度の PSD である. アクティブスタビラ イザを用いた場合，乗り心地に関連する $1 \sim 2 \mathrm{~Hz}$ の間 に存在するばね上共振周波数付近のロール角加速度の ピークをノーマルサスペンションとパッシブスタビラ イザの場合よりも抑えられていることが確認できる.

3.2 電動パワーステアリングの制御系設計 操 舵系式 (18) に対して， $H_{\infty}$ 制御理論を適用する. その 一般化プラントを図 7 のように構成する. 図 7 中の $n$ は観測ノイズである. $z_{11}, z_{12}, z_{13}, z_{21}$ は，それぞれ操 舵角 $\theta_{h}$, 操舵角速度 $\dot{\theta}_{h}$, センサトルク $T_{s}$, モ一夕卜 ルク $u_{s}\left(=T_{m}\right)$ に対応する制御量である. $\theta_{h}$ を周波数

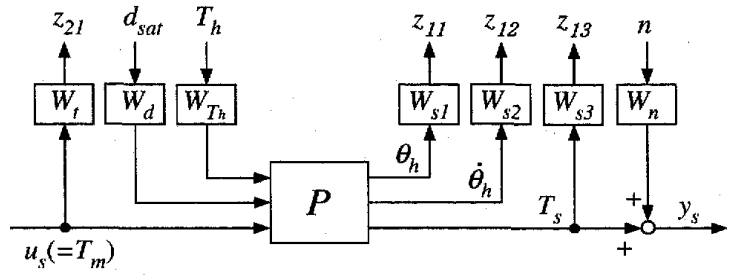

Fig. 7 Generalized plant

重み関数 $W_{s 1}$ で評価することにより，急なレーンチェ ンジを行うような場合のハンドル操作に対する実舵角 の応答性を向上させ， $\dot{\theta}_{h}$ を周波数重み関数 $W_{s 2}$ で評 価することにより実舵角の収束性を向上させることが できる. センサトルク $T_{s}$ を周波数重み関数 $W_{s 3}$ で評 価することにより $T_{s}$ を低減できるため，操舵角に対 するピニオン角の追従性を向上できる．また，八イパ スフィルタ型の周波数重み関数 $W_{t}$ の調整により高周 波数領域でモータトルク $T_{m}$ が過大となることを避け ることができる．ドライバの操舵トルク $T_{h}$ にはロー パスフィルタ型の周波数重み関数 $W_{T h}$ をかけ, ドライ バによるハンドル操作の周波数帯域を低周波数領域に 限定している.さらに，周波数重み関数 $W_{d}$ の調整に より操舵に伴って路面から操舵系に作用する外乱 $d_{s a t}$ の影響を抑制する。

アクティブスタビライザ付き車両モデルに対して図 8 に示すようにドライバモデルを含めた人間-車両系 ${ }^{(6)}$ を構成し, EPS の $H_{\infty}$ 制御系設計を行う. アクティブ スタビライザの制御器は車両モデル式 (11) の状態量 $\boldsymbol{x}$ に基づいて制御トルク $T_{a j}$ を計算し，ロール姿勢制御 を行う。また，操舵系は車両系に実舵角 $\delta_{f}$ を与える 一方で, 車両系から外乱 $d_{s a t}$ を受ける.そこで, EPS の制御器によって, 操舵アシスト制御を行う. そして, 目標コースにしたがって車両を走行させるために，車 両の横変位 $Y(t)$ を予測時間 $\tau_{p}$ の 2 次予測モデルに基 づくドライバモデルにフィードバックし，ドライバの 前方注視点での予測位置 $Y_{p}\left(t+\tau_{p}\right)$ を算出する.これ を，目標コース $Y_{r}(t)$ に対してドライバが予見した $\tau_{p}$ 時間後の目標位置 $Y_{r}\left(t+\tau_{p}\right)$ と比較し，予測誤差 $e_{p}$ を 求める. ドライバモデルには無駄時間 $\tau_{d}$ を加え, 比 例動作 $K_{p}$ により操舵卜ルク $T_{h}$ を操舵系に出力する.

図 8 の人間-車両系によりレーンチェンジシミュレー ションを繰り返し行い, 周波数重み関数を調整するこ とで, 適切な $H_{\infty}$ 制御器を求めた. その場合の周波数 重み関数を図 9 に示す. シミュレーションでは, 車速 $V$ を $22.2 \mathrm{~m} / \mathrm{s}(=80 \mathrm{~km} / \mathrm{h})$ 一定とし, 図 10(a) の点線で 示すように進行方向に $20 \mathrm{~m}$ かけて $3 \mathrm{~m}$ のレーンチエ ンジを終了するような目標コ一スを与えた。図 10(a), (b) にそれぞ机車両軌跡 $X-Y$ と操舵トルク $T_{h}$ を示す. 


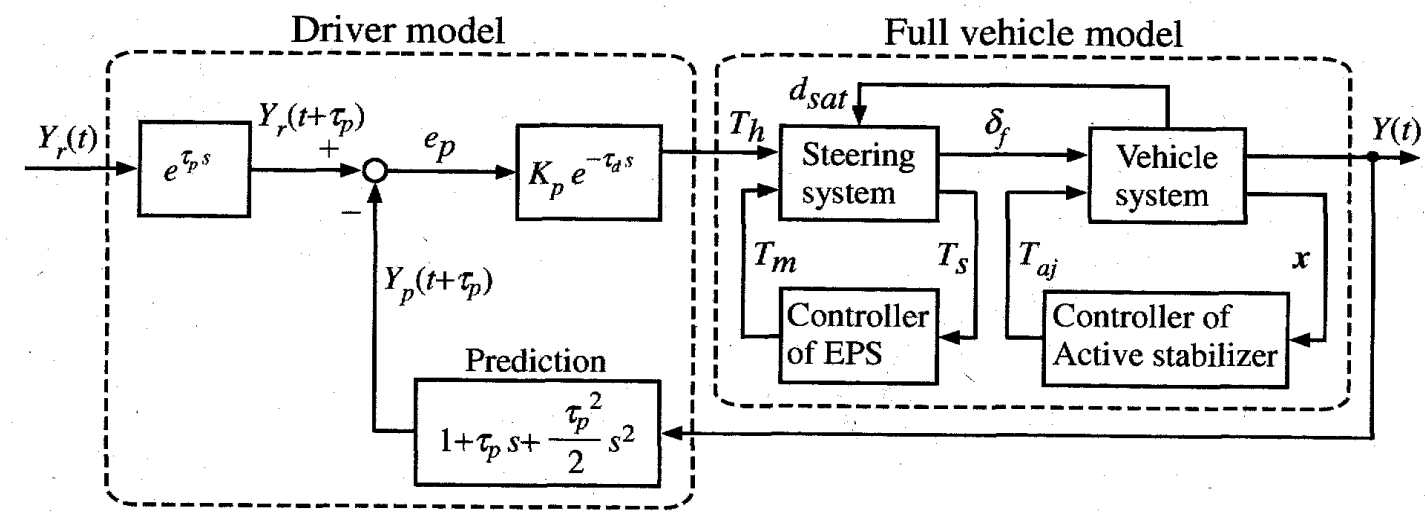

Fig. 8 Schematic of driver-vehicle system

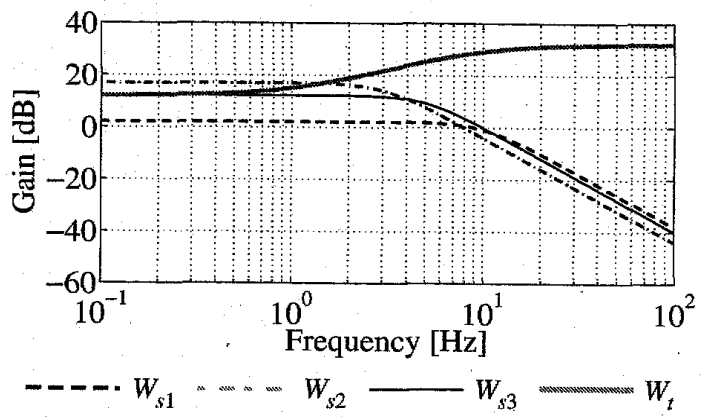

(a) Weighting functions for controlled variable

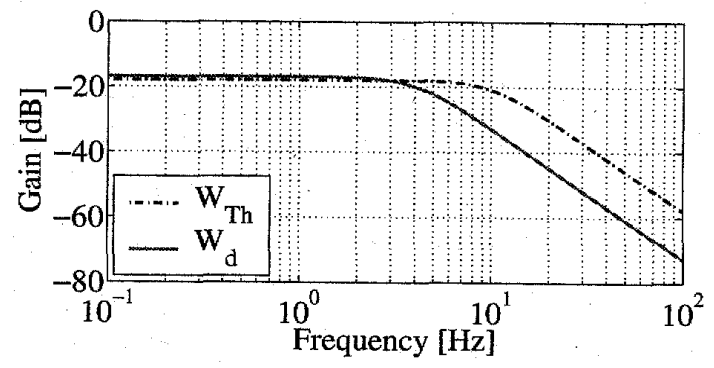

(b) Weighting functions for disturbance

Fig. 9 Weighting functions for $H_{\infty}$ controller

ここで, 細い実線はEPSなしのアクティブスタビライ ザ付き車両モデル，太い実線はEPS とアクティブスタ ビライザ付き車両モデルの応答である．周波数重み関 数の調整では，図 10(a)に示す目標コースへの整定性 を速め, 図 10(b) に示すように操舵トルクの収束性を 向上できるように配慮した。

\section{4. 分散制御による性能の評価}

4.1 スラローム走行 車速 $80 \mathrm{~km} / \mathrm{h}$ 一定のもと で, 目標コースの振幅を $2 \mathrm{~m}$ とし, 周波数 $0.3 \mathrm{~Hz}$ で操 舵するスラローム走行を行った. 図 11(a)から (c) は, 車両軌跡 $X-Y$, 操舵卜ルク $T_{h}$, ロール角 $\phi$ を示す. 破 線はEPS 付きノーマルサスペンション車両モデル，一 点鎖線は EPS とパッシブスタビライザ付き車両モデ ル，細い実線はEPSなしのアクティブスタビライザ付

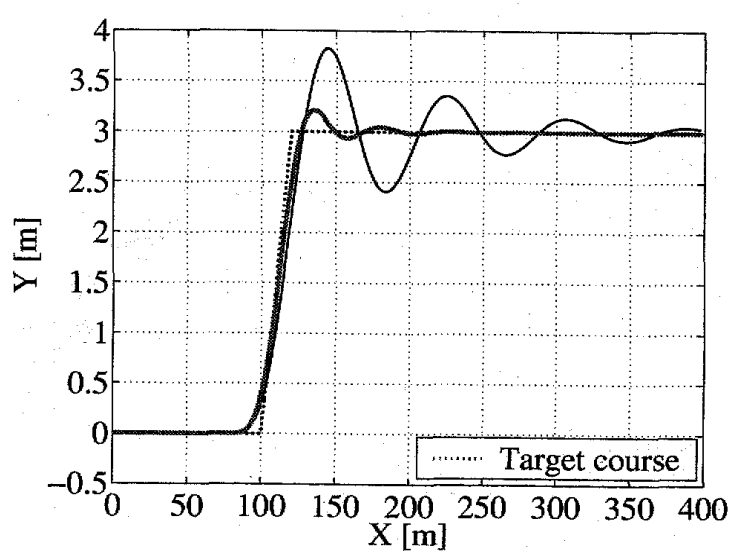

(a) $X-Y$

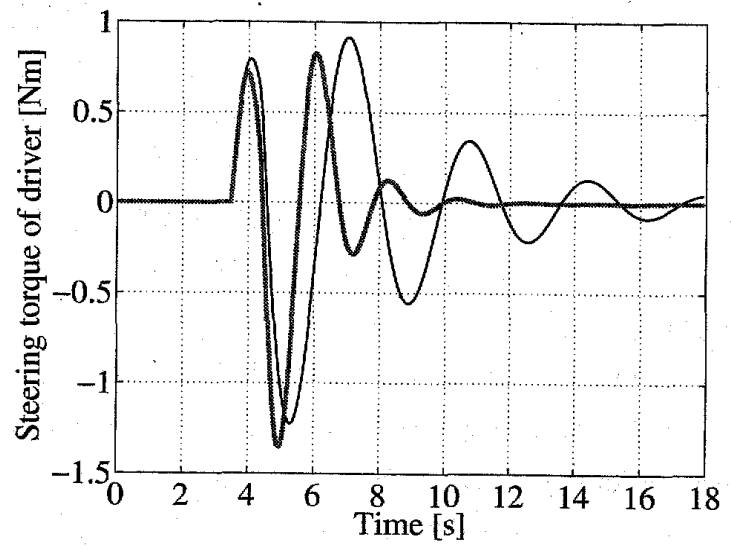

(b) $T_{h}$

\section{Active stabilizer}

Fig. 10 Lane change simulation for controller design

き車両モデル，太い実線はEPS とアクティブスタビラ イザ付き車両モデルの応答である.

EPS なしのアクティブスタビライザ付き車両モデル の場合, 図11(a), (b) から, 当該ドライバモデルの操舵 では目標コースに収束できないことがわかる.このと き, 操舵の周波数は一定であるが, 車両軌跡の振幅が 増加したことで，車体に作用する横力も増加してしま う.この影響で, 図11(c)に示すようにパッシブスタ 


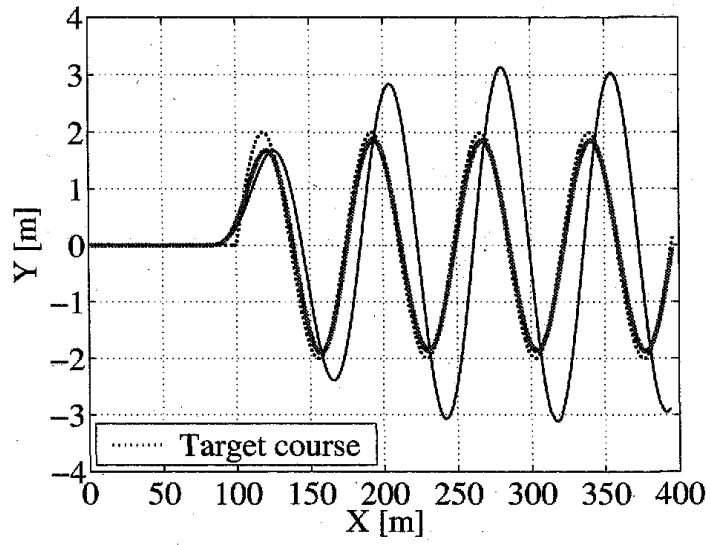

(a) $X-Y$

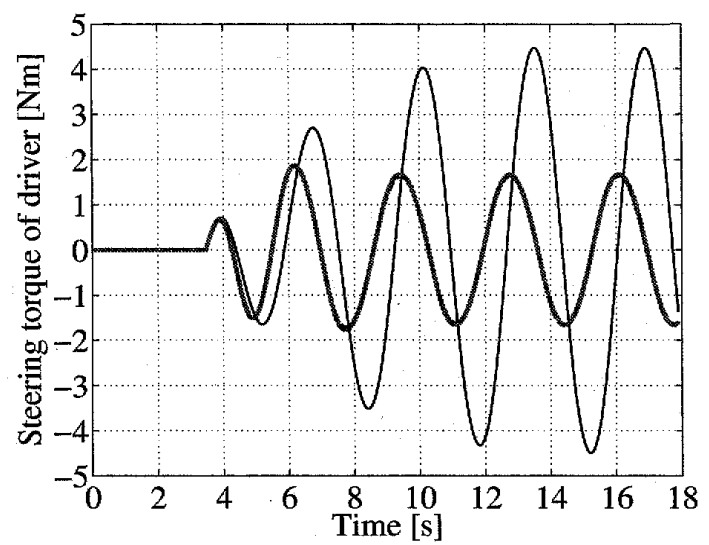

(b) $T_{h}$

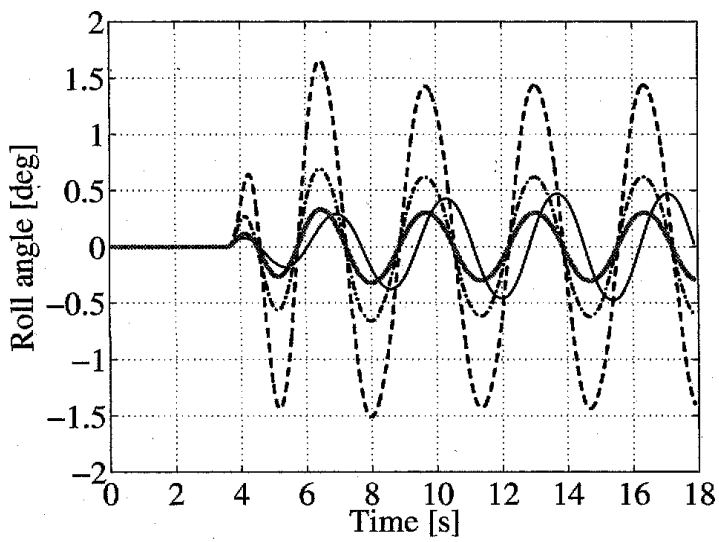

(c) $\phi$

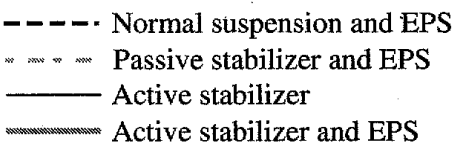

Fig. 11 Slalom simulation

ビライザの場合よりも操舵時のロール角を十分に低減 できていない.このようなドライバモデルに詨しても, EPS とアクティブスタビライザを同時に適用すること で，図11(c)からコーナリング時のロール角をパッシ ブスタビライザの場合の約 $1 / 2$ に低滅できていること
がわかる.これは，図11(a)に示すように，EPSによっ て目標コースへの収束性を向上させたことで, ロール 運動の要因となる車体重心に作用する横力を低減でき, スタビライザの負荷を軽減できたからである．また， 図 11(b)に示す操舵トルクは, ノーマルサスペンショ ン車両モデルと同等であり，設計した EPS の制御系 は，ロール運動を低減するために左右輪に作用するス タビライザ反力に対するロバスト性を確保していると いえる.

4.2 片輪乗り越し走行 車速 $80 \mathrm{~km} / \mathrm{h}$ で直進走 行させ, 時刻 $t=1 \mathrm{~s}$ で振幅 $0.1 \mathrm{~m}$, 距離 $8.89 \mathrm{~m}$ の三 角波状の凸路面を左輪が通過する片輪乗り越しシミュ レーションを行った.ここで, 後輪は前輪が外乱に遭 遇してから $\left(L_{f}+L_{r}\right) / V$ 時間後に同一外乱に遭遇する. 図 12(a)から (f) は路面不整を通過したときの車両軌

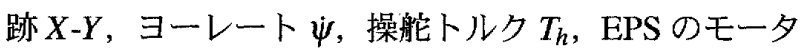
トルク $T_{m}$, ロール角 $\phi$, ロール角加速度 $\ddot{\phi}$ を示す.

図 12(a), (b) に示すように, EPS とアクティブスタ ビライザ付き車両モデルの場合, EPSにより目標コー スへの収束性を速め, アクティブスタビライザにより 左右のタイヤの接地性を改善することで, 操縦安定性 に関連するヨーレートの変動を抑制できている. また， 図 12(c), (d) から，操舵トルクとモータトルクの振幅 を低減できていることがわかる，これは，3 章の図 6 に示したとおり，アクティブスタビライザによって路 面外乱が車体に伝わらないように制御できるため，式 (16) で示した外乱 $d_{s a t}$ に含まれるタイヤの鉛直荷重変 動を抑制できた結果によるものである，このとき，図 12(e), (f) から，アクティブスタビライザの場合では, ノーマルサスペンションの場合と比較してロール角の 最大振幅を約 $1 / 8$ 以下に低減し，乗り心地に関連する ロール角加速度の収束性を約 2 倍に速めていることが 確認できる.

一方，ノーマルサスペンションおよびパッシブスタ ビライザの場合では，ロール角とロール角加速度の振 幅が抑えられていない。これはばね上共振周波数の影 響であり，パッシブスタビライザの場合ではスタビラ イザの高い剛性によって，最大振幅が最も大きくなつ ている.この影響で, 図 12(c) に示す操舵トルクの忍 答は振動的であり，図 12(d) のモータトルクとの位相 も逆であることから，不整路面でドライバがハンドル を取られてしまっていると考えられる. アクティブス タビライザの場合では，操舵トルクとモータトルクの 位相はほぼ同位相であり，ドライバが路面不整に対し て大きな影響を受けずに車両を目標コースへ収束させ ようとしているといえる。 


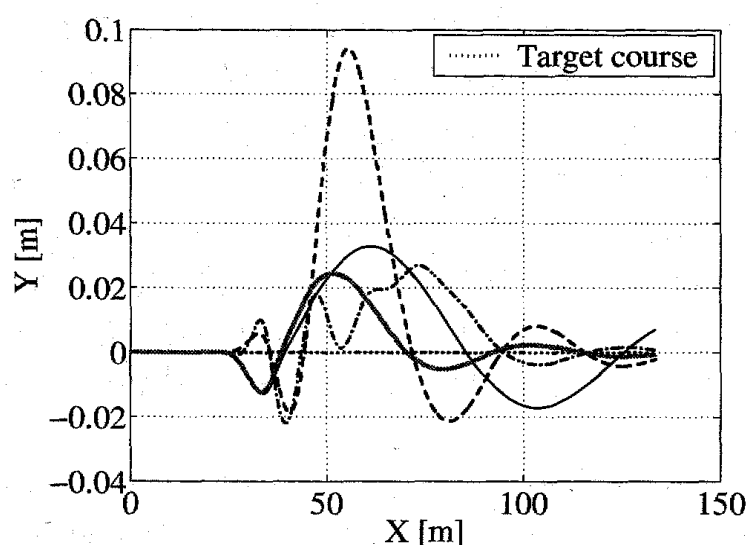

(a) $X-Y$

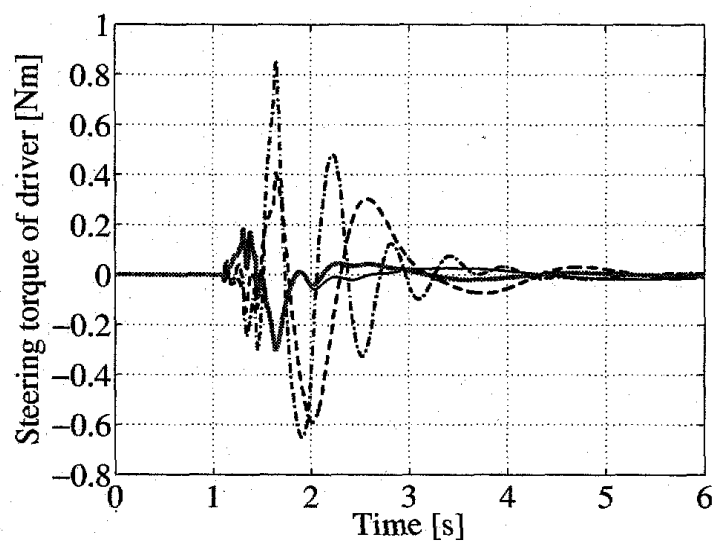

(c) $T_{h}$

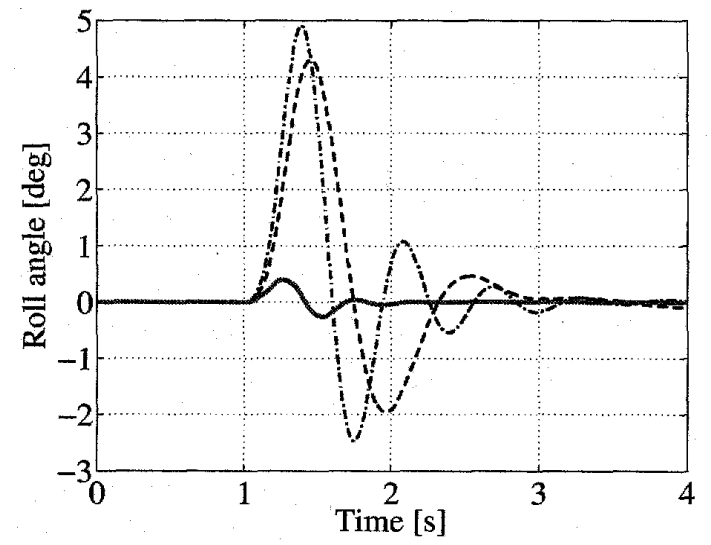

(e) $\phi$

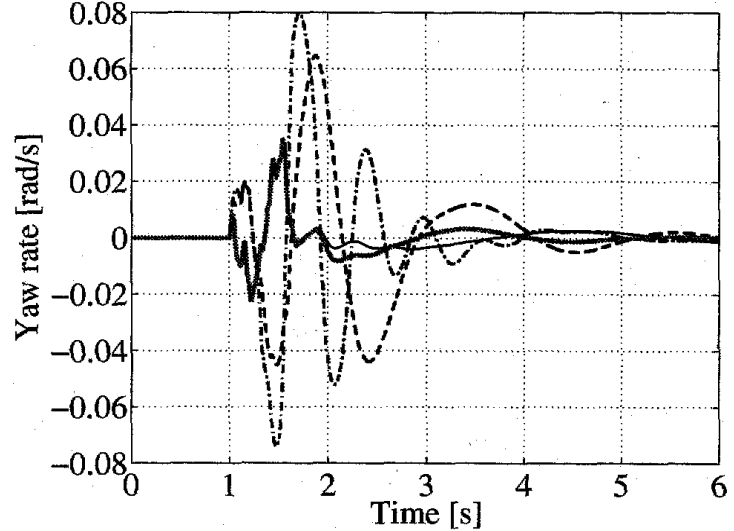

(b) $\dot{\psi}$

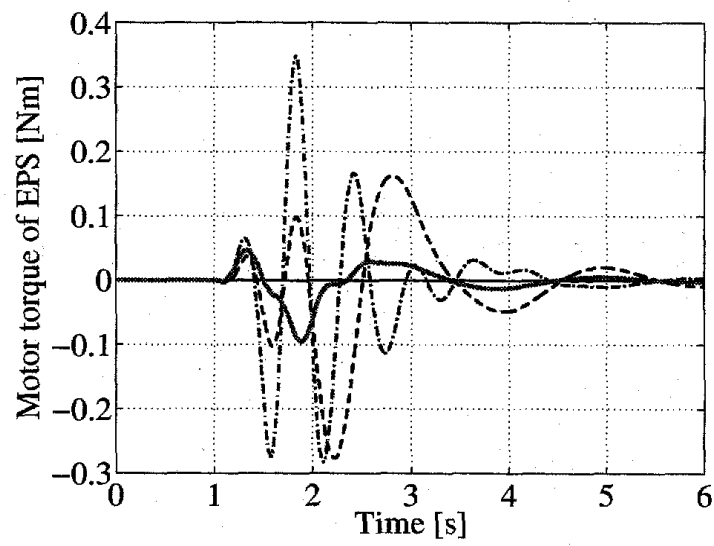

(d) $T_{m}$

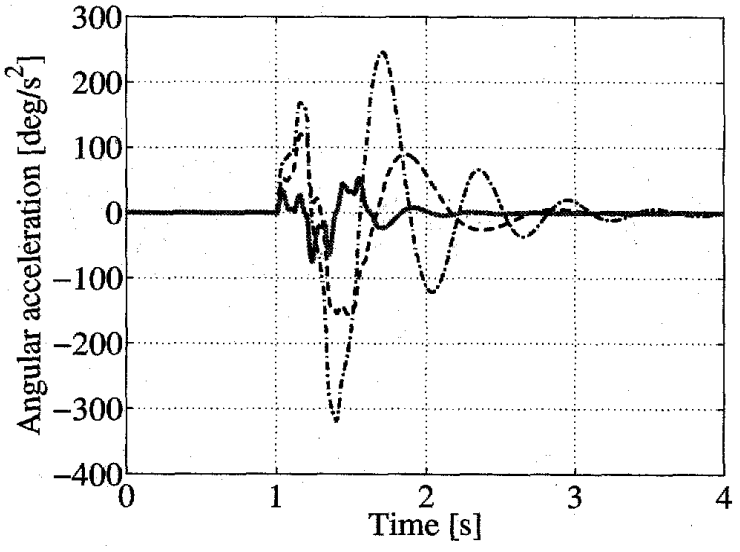

(f) $\ddot{\phi}$

Normal suspension and EPS $\ldots \ldots$ Passive stabilizer and EPS Active stabilizer Active stabilizer and EPS

Fig. 12 Driving simulation on rough road

\section{5.おわりに}

車両の操縦安定性を改善することを目的として，ア クティブスタビライザと EPS からなる分散制御系の 設計指針を示した. 従来のアクティブスタビライザと EPS 単体と比較して制御性能の優位性を示すものでは ないが, 分散制御系設計ではアクティブスタビライザ とEPS の両者の制御性能を考慮した。アクティブス
タビライザの制御系設計では, 操舵時のロール角の低 減のみならず, 不整路面でのタイヤの鉛直荷重変動に 起因する車体のロール振動を㧕制した，その結果，操 舵系に作用するセルフアライニングトルクの影響を抑 えられ, 操舵トルク, EPSのモータトルクを低減でき ることを示した．EPS の制御系設計では，操舵時に発 生するスタビライザ反カの影響を含むセルフアライニ 
ングトルクを外乱として考慮した. 周波数重み関数を 調整することで, ドライバの操舵をアシストし, 目標 コースへの整定性を速め, 車体重心に作用する横力の 低減を図った。

\section{謝 辞}

本研究の一部は文部科学省グローバル $\mathrm{COE}$ プログ ラム「環境共生・安全システムデザインの先導拠点」 に依るものであることを記し，謝意を表す。

付 録

車両モデルに用いた記号ならびに主要車両諸元を示 す（本文中に示したものを除く）.

\begin{tabular}{|c|c|}
\hline$b$ & スタビライザブッシュの取り付け位置 \\
\hline$C_{h}$ & ハンドル側のステアリング軸の減衰係数 \\
\hline$C_{m}$ & モータ側のステアリング軸の減衰係数 \\
\hline$C_{s j}$ & サスペンションの減衰係数 \\
\hline$C_{f}$ & 前輪の公称コーナリングパワー (片輪分) \\
\hline$d$ & $\begin{array}{l}\text { ロールセンタからサスペンション上部 } \\
\text { 取付け位置までの鉛直距離 }\end{array}$ \\
\hline$g$ & 重力加速度 \\
\hline$h_{r}, h_{p}$ & ロール, ピッチモーメントアーム長さ \\
\hline$I_{h}, I_{m}$ & ハンドル, モータの慣性モーメント \\
\hline$I_{r}, I_{p}, I_{y}$ & ロール, ピッチ, ヨー慣性モーメント \\
\hline$K_{h}$ & ステアリング軸の剛性 \\
\hline$K_{s j}$ & サスペンションのばね倸数 \\
\hline$K_{t}$ & タイヤ剛性 \\
\hline$L_{f}, L_{r}$ & 前輪, 後輪から車体重心までの水平距離 \\
\hline$M$ & 車両質量 $\left(=M_{b}+2 M_{t f}+2 M_{t r}\right)$ \\
\hline$M_{b}, M_{t j}$ & 車体質量, タイヤ質量 \\
\hline$s$ & サスペンションの取付け位置 \\
\hline$T_{j}$ & トレッド \\
\hline$T_{a j}$ & アクティブスタビライザトルク \\
\hline$T_{s j}$ & パッシブスタビライザトルク \\
\hline$v_{x i}, v_{y i}$ & 前後, 横タイヤ速度 \\
\hline$X-Y-Z$ & 路面固定座標系 \\
\hline$x_{b}-y_{b}-z_{b}$ & 車両固定座標系 \\
\hline$z_{i}, z_{t i}$ & 路面の鈶直変位, 車輪の鉛直変位 \\
\hline$\rho$ & サスペンションの取付け角度 \\
\hline$\beta, \beta_{t i}$ & 車両重心点, タイヤのスリップ角 \\
\hline$\theta$ & 車体のピッチ角 \\
\hline$\theta_{h}$ & 操舵角 \\
\hline$\xi$ & トレイル長さ \\
\hline$\phi$ & 車体のロール角 \\
\hline$\psi$ & 車両のヨ一角 \\
\hline$\omega_{t i}$ & 車輪の回転角速度 \\
\hline
\end{tabular}

添字 $i \quad$-左前輪, 2-右前輪, 3-左後輪, 4-右後輪 添字 $j \quad f$-前輪, $r$-後輪

$C_{f}=38522 \mathrm{~N} / \mathrm{rad}, C_{h}=0.3 \mathrm{Nms} / \mathrm{rad}, C_{m}=0.55 \mathrm{Nms} / \mathrm{rad}$, $C_{s f}=C_{s r}=1650 \mathrm{Ns} / \mathrm{m}, h_{r}=0.486 \mathrm{~m}, h_{p}=0.56 \mathrm{~m}$, $I_{h}=0.0294 \mathrm{kgm}^{2}, I_{m}=0.0729 \mathrm{kgm}^{2}, I_{r}=500 \mathrm{kgm}^{2}$, $I_{p}=1500 \mathrm{kgm}^{2}, I_{y}=2453 \mathrm{kgm}^{2}, K_{h}=134.6 \mathrm{Nm} / \mathrm{rad}$, $K_{s f}=23000 \mathrm{~N} / \mathrm{m}, K_{s r}=21500 \mathrm{~N} / \mathrm{m}, K_{t}=240000 \mathrm{~N} / \mathrm{m}$, $K_{s t}=K_{s t r}=5150 \mathrm{~N} / \mathrm{rad}, L_{f}=1.2 \mathrm{~m}, L_{r}=1.4 \mathrm{~m}$, $M=1460 \mathrm{~kg}, M_{b}=1300 \mathrm{~kg}, M_{t f}=M_{t r}=40 \mathrm{~kg}, N=18.4$, $T_{f}=T_{r}=1.5 \mathrm{~m}, \rho=80 \times(\pi / 180) \mathrm{rad}, \xi=0.0715 \mathrm{~m}$

\section{文献}

(1) Hayashi, R., Suda, Y., Nakano, k., Performance of a Roll Stabilizer Imitated by Electromagnetic Suspensions, Transactions of the Japan Society of Mechanical Engineers, Series C, Vol.73, No.733, (2007), pp.24732478

(2) Takahashi, M., Kumamaru, T., Yoshida, K., Integrated Controller Design for Automotive Semi-Active Suspension Considering Vehicle Behavior with Steering Input, Transactions of the Japan Society of Mechanical Engineers, Series $C$, Vol.74, No.744, (2008), pp.2015-2022

(3) Konik, D., Development of the Dynamic Drive for the new 7 Series of the BMW Group, International Journal of Vehicle Design, Vol.28, No.1/2/3, (2002), pp.131-149

(4) Buma, S., Ookuma, Y., Taneda, A., Suzuki, K., Cho, J, Kobayashi, M., Synthesis and Development of Electric Active Stabilizer Suspension System, Transactions of the Japan Society of Mechanical Engineers, Series C, Vol.74, No.748, (2008), pp.2827-2836

(5) Yamamoto, K., Nishimura, H., Control of Suspension System with Active Stabilizer Considering Roll Reduction and Ride Comfort, Transactions of the Japan Society of Mechanical Engineers, Series C, Vol.75, No.753, (2009), pp.1327-1335

(6) Yoneda, A., Shimizu, Y., Miyoshi, T., Tsujioka, T., A Study of Control Performance Depends on EPS Motor Cogging Torque, 2006 JSAE Annual Congress (Spring), No. 10-6, (2006-5), pp.15-20

(7) Takehara, S., Yoshioka, T., Improvement of Steering and Vehicle Characteristics due to Electric Power Assist Steering with Disturabance Observer, Transactions of the Japan Society of Mechanical Engineers, Series C, Vol.70, No.698, (2004), pp.2913-2916

(8) Arai, A., Nishimura, H., Mouri, H., Kubota, M., GainScheduled Control of Electric Power Steering, The 10th Symposium on Motion and Vibration Control, (2007-8), pp.43-48

(9) Baffet, G., Charara, A., Dherbomez, G., An Observer of Tire-Road Forces and Friction for Active Security Vehicle Systems, IEEE/ASME TRANSACTIONS ON MECHATRONICS, Vol.12, No. 6, (2007), pp.651-661

(10) Society of Automotive Engineers of Japan, Automotiove Engineers Handbook, Basic and Theory Edition (in Japanese), Society of Automotive Engineers of Japan, (2004), pp.352-356 